\begin{tabular}{|c|c|c|}
\hline SALA & $\begin{array}{c}\text { Proceeding } \\
\text { International Conference on Islamic Educational Guidance and Counseling } \\
\text { 9 December 2021 } \\
\text { E-ISSN: } 2827-9581 \\
\text { Website: http://conference.iainsalatiga.ac.id/index.php/iciegc }\end{array}$ & HIm. 257-266 \\
\hline
\end{tabular}

\title{
PELAKSANAAN KONSELING KELOMPOK OLEH GURU BIMBINGAN DAN KONSELING DALAM MEMBANGUN HARMONISASI ANTARA ETNIK LAMPUNG DAN ETNIK JAWA PADA PESERTA DIDIK DI SEKOLAH
}

\author{
Arfani Fernando Fahmi ${ }^{1}$, Nevrisa Kharisma Putri ${ }^{2}$, Elly Zetina ${ }^{3}$, Meigo Anugrah Jaya ${ }^{4}$, \\ Hendra Harmi ${ }^{5}$ \\ $1,2,3,4,5$ IAIN Curup
}

\begin{tabular}{|c|c|}
\hline Informasi Artikel & ABSTRACT \\
\hline $\begin{array}{l}\text { Penulis Korespondensi: } \\
\text { Arfani Fernando Fahmi } \\
\text { Email: } \\
\text { Arfanifernandof@gmail.com }\end{array}$ & $\begin{array}{l}\text { This article aims to see how the implementation of group counseling } \\
\text { by BK teachers in building harmonization between the Lampung } \\
\text { Ethnic and the Javanese Ethnic. The research method in this study is } \\
\text { qualitative using a research design, namely case studies or multi-case } \\
\text { single-site case study designs. The research sample was taken based } \\
\text { on certain criteria using purposive sampling technique, so that a } \\
\text { sample of } 6 \text { respondents was obtained consisting of } 5 \text { students and } 1 \\
\text { Guidance and Counseling teacher. The results of the study stated that } \\
\text { the implementation of group counseling from BK teachers at SMK N } \\
1 \text { Kotabumi was carried out as a follow-up effort in building ethnic } \\
\text { harmonization, especially on this subject, namely the Lampung and } \\
\text { Javanese ethnicities. The implementation of group counseling begins } \\
\text { with finding students with criteria that meet and relate to research } \\
\text { variables, then proceed with starting group counseling. In practice, } \\
\text { counseling is carried out in several stages and with the dynamics of } \\
\text { the groups present in it so as to achieve the evaluation of the expected } \\
\text { results. }\end{array}$ \\
\hline
\end{tabular}

Keyword: Implementation of group counseling; harmonization between ethnics

\begin{tabular}{l}
\hline ABSTRAK \\
Artikel ini bertujuan untuk melihat bagaimana pelaksanaan konseling \\
kelompok oleh guru BK dalam membangun harmonisasi antara Etnik \\
Lampung dan Etnik Jawa. Metode penelitian pada penelitian ini yaitu \\
kualitatif dengan menggunakan desain penelitian yaitu studi kasus \\
atau multi-case single-site case study design. Sampel penelitian \\
diambil berdasarkan kriteria tertentu menggunakan teknik purposive \\
sampling, sehingga didapatkan sampel sebanyak 6 rang responden \\
yang terdiri dari 5 peserta didik dan 1 guru Bimbingan dan Konseling. \\
Hasil kajian menyatakan bahwa pelaksanaan konseling kelompok \\
dari guru BK di SMK N 1 Kotabumi dilakukan sebagai upaya tindak \\
lanjut dalam membangun harmonisasi antar etnik terutama pada \\
pokok permasalahan ni yaitu etnik Lampung dan Jawa. Pelaksanaan \\
konseling kelompik dimulai dari pencarian peserta didik dengan \\
kriteria yang memenuhi dan berkaitan dengan variabel penelitian, \\
kemudian dilanjutkan dengan mulai melakukan konseling kelompok. \\
Dalam pelaksanaannya, konseling dilakukan dengan beberapa \\
tahapan dan dengan dinamika kelompok yang hadir di dalamnya \\
sehingga mencapai pada evaluasi hasil yang diharapkan.
\end{tabular}


Kata kunci: Pelaksanaan konseling kelompok; harmonisasi antar etnik

\section{PENDAHULUAN}

Pendidikan ialah sebagai bentuk usaha sadar dan terencana untuk mewujudkan suasana belajar dan proses pembelajaran untuk peserta didik secara aktif mengembangkan potensi dirinya untuk memiliki kekuatan spiritual keagamaan, pengendalian diri, kepribadian, kecerdasan, akhlak mulia, serta keterampilan yang diperlukan dirinya dan masyarakat. Pendidikan dapat diartikan sebagai usaha sadar dan sistematis untuk mencapai taraf hidup atau untuk kemajuan lebih baik. Secara sederhana, pendidikan adalah proses pembelajaran bagi peserta didik untuk dapat mengerti, paham, dan membuat manusia lebih kritis dalam berpikir (Herawati, 2018). Sedangkan pendidikan dalam arti luas merupakan bantuan atau pertolongan yang diberikan oleh seseorang kepada orang lain untuk mengembangkan dan memfungsionalkan rohani (pikiran, rasa, karsa, cipta dan budi nurani) manusia dan jasmani (panca indra dan ketrampilan-ketrampilan) manusia agar meningkatkan wawasan pengetahuannya. Adapun tujuan pendidikan tidak selalu berjalan dengan lancar karena penyelenggaraan pendidikan bukan kegiatan yang sederhana tetapi sangat kompleks. Tercapainya hasil belajar yang optimal sangat dipengaruhi oleh sikap dan tingkah laku siswa selama mengikuti proses pembelajaran. Agar proses belajar mengajar menjadi lancar maka siswa harus mematuhi tata tertib dengan penuh rasa disiplin yang tinggi (Megantari, dkk., 2014).

Jadi dapat disimpulkan bahwa pendidikan merupakan usaha dan proses pembelajaran yang diberikan kepada peserta didik agar peserta didik dapat mengembangkan segala potensi dirinya dengan begitu peserta didik memilki segala kemampuan yang berfungsi untuk beradaptasi dengan baik dilingkungan masyarakat. Di dalam proses pendidikan tentu saja banyak sekali hambatan dan tantangan bagi peserta didik ataupun seorang guru untuk mencapai tujuan pendidikan itu sendiri, dengan latar belakang negara Indonesia yang kaya akan perbedaan dalam adat, budaya, agama, ras, dan etnik (Multikultural) menjadi salah satu tantangan yang harus dihadapi dalam proses pendidikan karena dengan adanya perbedaan ini dapat mencul gesekan atau konflik dilingkungan pendidikan terutama pada peserta didik. Gesekan atau konflik dapat muncul jika peserta didik tidak dapat saling memahami satu sama lain, merasa bahwa sukunya lah yang paling baik dari pada suku lain sehingga terjadi perundungan atau diskriminasi suku, dan rendahnya toleransi antar sesama. Hal ini juga dipengaruhi oleh penanaman nilai-nilai 
toleransi didalam keluarga, tidak heran di era saat ini sebagai orang tua dan keluarga masih ada yang menanamkan nilai negatif pada anak, mengajarkan anak bahwa tidak ada suku yang paling baik selain sukunya sendiri dan menganggap suku lain rendah.

Keragaman Indonesia sebuah takdir dan keberkahan. Merupakan pemberian Tuhan Yang Mencipta, bukan untuk di langgar tapi untuk diterima dengan baik (taken for granted). Sebagai Negara yang dianugerahi keberagaman etnis, suku, budaya, bahasa, dan agama di dunia. Negara dengan dominasi paling banyak dipeluk oleh masyarakat di dunia, ada ribuan suku, bahasa dan aksara daerah, dan kepercayaan lokal di setiap daerah (Hidayat, dkk., 2019). Perbedaan inilah yang menjadi kelebihan dan nilai positif bagi masyarakat Indonesia karena dengan berbagai perbedaan yang dimilki Indonesia (multikultural) tetapi masyarakat Indonesia tetap saling menghargai satu sama lain, dapat hidup berdampingan serta saling bergotong royong. Sleeter mengatakan bahwa pendidikan multikultural sekumpulan proses yang dilakukan oleh sekolah untuk menentang kelompok yang menindas. Pengertianpengertian ini tidak sesuai dengan konteks pendidikan di Indonesia karena Indonesia memiliki konteks budaya yang berbeda dari Amerika Serikat walaupun keduanya memiliki bangsa dengan multi-kebudayaan. Pendidikan multikultural sebenarnya merupakan sikap "peduli" dan mau mengerti (difference) atau "politics of recognition" politik pengakuan terhadap orang-orang dari kelompok minoritas. Pendidikan multikultural melihat masyarakat secara lebih luas. Berdasarkan pandangan dasar bahwa sikap "indiference" dan "non-recognition" tidak hanya berakar dari ketimpangan struktur rasial, tetapi paradigma pendidikan multikultural mencakup subjek-subjek mengenai ketidak adilan, kemiskinan, penindasan, dan keterbelakangan kelompok-kelompok minoritas dalam berbagai bidang: sosial, budaya, ekonomi, pendidikan, dan lain sebagainya (Muzaki \& Tafsir, 2018). Sebagai sebuah bangsa yang majemuk, indonesia rentan atas problematika horizontal yang di sebabkan adanya berbagai keberagaman dalam masyarakatnya. Problematika tersebut tentu saja dapat memecah-belah persatuan dan kesatuan bangsa jika tidak adanya manejemen konflik yang baik dari pemerintah dan masyarakat Indonesia sendiri. Para tokoh pendiri bangsa ini mengerti betul potensi adanya konflik yang mungkin dimunculkan dari keragaman yang ada di indonesia sehingga kalimat Bhineka Tunggal Ika dikutip dari kitab Sutasoma dan

Di provinsi Lampung bukan hanya didiami masyarakat asli suku Lampung namun juga didiami masyarakat pendatang salah satunya suku Jawa dan memang sangat banyak dikarenakan adanya transmigrasi. Transmigrasi di Lampung berasal dari berbagai daerah 
dan berbagai suku bangsa, akan tetapi suku bangsa Jawa menjadi suku bangsa yang paling mendominasi transmigrasi tersebut. Letak daerah Lampung yang tidak terlalu jauh dengan Jawa menjadi salah satu alasannya. Hal itu menyebabkan banyaknya suku Jawa di Lampung. Tentu saja hal ini juga sangat berpengaruh terhadap dunia pendidikan, dengan banyaknya transmigrasi dan menetapnya suku Jawa di Lampung sudah dipastikan bahwa di lingkungan pendidikan peserta didik bukan hanya suku asli Lampung tetapi banyak juga suku pendatang salah satunya yaitu suku Jawa (Miyanti, dkk., 2017). Di dunia pendidikan terutama di sekolah dengan adanya keberagaman peserta didik seperti perbedaan etnik tentu saja hal ini bisa menjadi salah satu penyebab konflik. Banyak jenis konflik dalam kehidupan sehari-hari dihadapi oleh umat manusia, seperti konflik yang dimulai dari dalam diri sendiri; lingkungan sekolah; lingkungan masyarakat; antar organisasi lokal, nasional, dan internasional; sampai dengan konflik antar kelompok bangsa dan negara. Sebagaimana telah kita ketahui bahwa konflik merupakan bagian dari masalah yang tidak terpisahkan dari kehidupan manusia di berbagai tempat di seluruh permukaan bumi ini. Dengan kata lain, konflik secara sempit atau luas akan terjadi kapan pun dan di mana pun, baik secara spontan atau tanpa terencana maupun secara terencana. Sebenarnya konflik yang disebabkan antara perbedaan etnik bukan hal baru yang terjadi di Indonesia baik dilingkungan masyarakat, organisasi ataupun sekolah.

Permasalahan atau konflik antara etnik Lampung dan etnik Jawa sudah pasti terjadi di lingkungan masyarakat. masyarakat pendatang, khususnya etnik Jawa sering menjadi korban pembegalan, perampokan dan penjarahan yang dilakukan oleh masyarakat etnis Lampung yang merupakan pribumi. Masyarakat pendatang merasa terancam, terintimidasi, tidak aman, nyaman, hidup dalam ketidak tenangan dan ketenteraman, meskipun hal ini belum tentu benar adanya. Sebagian dari masyarakat Lampung juga melabel masyarakat jawa dengan sebutan "Jamet atau Jawa Burak" istilah-istilah saat ini yang diciptakan dan sering kita dengar. Sedangkan Masyarakat Jawa memandang, menilai dan meyakini bahwa penduduk lokal Lampung memiliki perilaku kurang baik, kasar, sewenang-wenang, mau menang sendiri, arogan, malas dan kurang menerima transmigrasi. Kemudian suku Jawa memberikan pelebelan negatif terhadap sebutan tertentu seperti "mbilung”. Mbilung adalah sebuah lebel yang diberikan orang Jawa kepada orang Lampung yang diibaratkan layaknya tokoh antagonis. Anggapan negatif antar etnik Lampung dan etnik Jawa ini sudah berlangsung cukup lama dan tentu saja juga berpengaruh terhadap peserta didik yang saat ini sedang menempuh pendidikan. Hal ini tidak bisa terus dibiarkan karena besar 
kemungkinan konflik, perundungan antar etnik atau suku akan terjadi dilingkungan sekolah bahkan bisa lebih dari itu.

Berdasarkan hasil wawancara peserta didik yang bersuku Lampung bahwa mereka yang memang asli suku Lampung pernah mendapatkan perundungan dari suku Jawa ketika disekolah dan hal ini membuat mereka tidak nyaman dan ingin membalas perlakuan mereka. Peserta didik yang bersuku Lampung pernah mendapatkan perundungan bahwa suku Lampung itu tidak sopan, keras, mau menang sendiri dan berani hanya dikampung sendiri.

Berdasarkan hasil wawancara peserta didik yang bersuku Jawa bahwa mereka pernah mendapatkan perundungan atau ejekan dari suku asli Lampung yang mengatakan mereka dengan sebutan Jamet atau Jawa burak yang menganggap mereka tidak bisa menyesuaikan kondisi ketika berpenampilan bahkan sebagian ada yang mendapatkan ejekan secara fisik.

Maka perlu adanya peran guru bimbingan dan konseling dalam membangun harmonisasi antara etnik Lampung dan etnik Jawa pada peserta didik sebagai upaya mencegah gesekan, konflik serta perundungan antar etnik disekolah. Penelitian ini bertujuan untuk mengetahui bagaimana penerapan konseling kelompok yang dilakukan guru bimbingan dan konseling dalam membangun harmonisasi antara peserta didik etnik Lampung dan peserta didik etnik Jawa sehingga tidak terjadi konflik, perundungan etnik, dapat hidup berdampingan, dan memahami perbedaan.

Konseling kelompok ialah suatu bantuan yang diberikan pada individu dalam situasi kelompok sebagai upaya pencegahan dan penyembuhan serta diarahkan pada pemberian kemudahan dalam perkembangan dan pertumbuhannya. Konseling kelompok diyakini dapat membantu siswa secara individual dan mendapatkan pembahasan dan pengentasan masalah yang mereka hadapi melalui dinamika kelompok (Sari, dkk., 2020). Dengan penerapan konseling kelompok oleh guru bimbingan dan konseling diharapkan dapat membangun harmonisasi antar peserta didik etnik Lampung dan peserta didik etnik Jawa.

\section{METODE}

Metodelogi pada penelitian ini yaitu menggunakan metode kualitatif dengan pendekatan ataudesain penelitian yaitu studi kasus atau multi-case single-site case study design, dimana desain ini diterapkan untuk meneliti suatu fenomena yang akan dikaji (Creswell, 2017). Adapun peneliti berpendapat bahwa desain ini cocok digunakan dalam penelitian karena pada penelitian ini akan dilihat pelaksanaan konseling kelompok yang 
dilakukan oleh guru BK dalam membangun harmonisasi antara etnik Lampung dan Jawa di SMK N 1 Kotabumi. Teknik pengumpulan data dilakukan dengan purposive sampling di mana peneliti menetapkan kriteria tertentu. Kriteria tersebut diantaranya: 1) Berdasarkan rekomendasi dari guru $\mathrm{BK}$; 2) Peserta didik terindikasi memiliki permasalahan terkait variabel penelitian; \& 3) Peserta didik bersedia menjadi responden.

Selanjutnya, sampel ditetapkan yaitu sebanyak 6 orang yang terdiri dari 5 peserta didik dan 1 orang guru BK. Instrumen penelitian yang digunakan untuk mengambil data yaitu wawancara yang dilakukan pada 6 orang responden. Hasil dari wawancara tersebut di analisis sehingga membentuk sebuah data yang dapat dilihat sebagai hasil penelitian dengan tujuan yaitu melihat penerapan konseling kelompok oleh guru BK dalam membangun harmonissi antara etnik Lmpung dan Etnik Jawa.

Kisi-kisi wawancara tersebut dibagi menjadi dua yaitu untuk guru BK dan untuk peserta didik. Kisi-kisi wawancara guru BK diantaranya sebagai berikut: 1) Apakah kasus ketidak harmonisan dalam etnik ini benar terjadi di sekolah?; 2) Seperti apa bentuk konflik yang sering terjadi?; 3) Apa yang biasanya memicu terjadinya konflk tersebut?; 4) Sejauh ini langkah apa yang telah diambil guru BK untuk menindak lanjuti kasus atau permasalahan tersebut?; 5) Bagaimana persiapan konseling kelompok yang diterapkan tersebut?; 6) Apa tujuan dalam pelaksanaan konseling kelompok tersebut?; 7) Bagaimana langkah dalam pelaksanaan konseling kelompok untuk mengatasi hal tersebut?; dan 8) Bagaimana hasil yang didapat setelah melakukan konseling kelompok?

Adapun kisi-kisi wawancara untuk peserta didik, diantaranya: 1) Apakah saudara pernah terlibat konflik karena berbeda suku?; 2) Biasanya konflik seperti apa yang saudara alami terkait hal tersebut?; 3) Apakah ada penanganan dari pihak sekolah?; 4) Apakah benar guru BK melakukan konseling kelompok terkait hal tersebut?; 5) Apa saja yang saudara lakukan ketika mengikuti kegiatan konseling kelompok?; 6) Apa yang saudara rasakan dan pikirkan terkait konflik tersebut setelah mengikuti kegiatan konseling kelompok?; dan 7) Setelah melakukan kegiatan konsleing kelompok, apakah ada perubhan persepsi saudara terkait perbedaan suku tersebut?.

\section{HASIL DAN BAHASAN}

\section{Hasil}

Permasalahan Sara memang benar terjadi disekolah ini, seperti perundungan etnik atau suku yaitu suku Lampung dan suku Jawa sehingga terjadi konflik dan membuat peserta didik bersosialisasi hanya dengan sesama sukunya karena takut dapat perundungan atau 
ejekan bahkan ada yang sampai bertengakar. Sebenarnya pemicu masalah ini faktornya sangat banyak seperti kurangnya pemahaman antar suku, rendahnya toleransi, kurang harmonis dengan suku lain, sulit beradaptasi dengan suku lain, masih ada penanaman nilai negatif didalam keluarga bahwa suku yang paling ungggu hanya suku mereka sendiri sedangkan suku lain dianggap rendah. Ketika masalah perundungan ini terjadi sebagai guru bimbingan dan konseling tentu memberikan layanan yang tepat agar permasalahan ini dapat terselesaikan yaitu dengan memberikan layanan konseling kelompok karena layanan konseling kelompok dianggap efektif dalam mengatasi permasalahan ini dan tentunya dapat membangun harmonisasi antar etnik Lampung dan etnik Jawa, sehingga peserta didik dapat hidup berdampingan dilingkungan sekolah. Dalam prosesnya, konseling kelompok menerapkan dinamika kelompok yang di mana setiap anggota kelompok dapat memberikan pendapat, tanggapan dan saran setelah angggota lain menjelaskan masalahnnya, dengan begitu peserta didik yang mengalami permasalahan ini dapat menemukan solusi dari pendapat anggota kelompok lain. Di samping itu proses konseling kelompok dapat membagun kedekatan dan keakraban antar etnik Lampung dan etnik Jawa sehingga terjadi proses saling memahami antar peserta didik etnik Lampung dan etnik Jawa.

Sebagai guru bimbingan dan konseling persiapan yang dilakukan dalam melaksanakan atau menerapkan sesi konseling kelompok yang pertama adalah memanggil dan menentukan peserta didik yang memiliki permasalahan atau konflik antar etnik Lampung dan etnik Jawa, kemudian menentukan jadwal kapan dilaksanakannya sesi konsleing kelompok.

Setelah melakukan sesi konseling kelompok 4-5 sesi pada peserta didik yang mengalami konflik antar etnik Lampung dan etnik Jawa, ada perubahan yang signifikan terhadap peserta didik etnik Lampung dan peserta didik etnik Jawa. perubahan yang dirasakan kearah yang leih positif, seperti sudah cukup saling memahami antar karakter etnik atau suku, sudah saling tegur sapa, peserta didik menyadari bahwa setiap suku atau etnik memiliki kelebihan dan kekurangan masing-masing, tidak saling mengganggu dan melakukan perundungan lagi meskipun pada awal sesi konseling masih sangat terlihat ego masing-masing peserta didik antar etnik Lampung dan etnik Jawa, sama-sama ingin menunjukan siapa yang benar dan salah dalam permasalahan ini.

Jadi hasil dari penelitian ini menyatakan bahwa pelaksanaan konseling kelompok dari guru BK di SMK N 1 Kotabumi dilakukan sebagai upaya tindak lanjut dalam membangun harmonisasi antar etnik terutama pada pokok permasalahan ni yaitu etnik Lampung dan 
Jawa. Pelaksanaan konseling kelompik dimulai dari pencarian peserta didik dengan kriteria yang memenuhi dan berkaitan dengan variabel penelitian, kemudian dilanjutkan dengan mulai melakukan konseling kelompok. Dalam pelaksanaannya, konseling dilakukan dengan beberapa tahapan dan dengan dinamika kelompok yang hadir di dalamnya sehingga mencapai pada evaluasi hasil yang diharapkan.

\section{Bahasan}

Diketahui bahwa sampel diambil dengan menggunakan teknik purposive sampling. Di mana pada teknik ini, peneliti menggunakan kriteria tertentu sehingga mendapatkan sampel yang sesuai dengan penelitian. Sampel yang didapat yaitu sejumlah 6 orang responden yang terdiri dari 5 peserta didik dan 1 guru BK.

Tujuan dari penelitian ini yaitu untuk melihat pelaksanaan konseling kelompok oleh Guru BK dalam membangun harmonisasi antar etnik dalam hal ini etnik Lampung dan Jawa sebagai variael penelitian. Dalam melihat pelaksanaan, peneliti merujuk pada teori tahapan dalam melakukan konseling kelompok. Adapun tahapan tersebut diantaranya; 1). Tahap Pembentukan di mana pada tahap ini merupakan tahap pengenalan, tahap pelibatan diri atau tahap memasukkan diri ke dalam kehidupan suatu kelompok. Winkel menjelaskan bahwa tahap ini merupakan titik awal bagi pengembangan hubungan antar pribadi (working relationship) yang baik, yang diikuti dengan pembicaraan terbuka dan terarah pada penyelesaian masalah (Winkel \& Hastuti, 2004); 2). Tahap Peralihan di mana peranan pemimpin kelompok pada tahap ini yaitu menerima suasana yang ada secara sabar dan terbuka, tidak mempergunakan cara-cara yang bersifat langsung atau mengambil kekuasaannya, mendorong dibahasnya suasana perasaan, dan membuka diri contohnya seperti penuh empati (Priyatno, 1995); 3). Tahap Kegiatan atau biasa disebut dengan tahap inti dimana tujuan dari tahap ini yaitu mengungkapkan apa yang dirasakan, dialami, dan dipikirkan anggota kelompok (konseli) terkait permasalahannya yang diikuti oleh anggota kelompok lainnya. Semua anggota berpartisipasi secara aktif. Pada tahap kegiatan, Winkel membaginya dalam tiga tahapan, yaitu penjelasan masalah, pengalian latar belakang, dan penyelesaian masalah (Winkel \& Hastuti, 2004); 4). Tahap Pengakhiran dimana pada tahapan ini pemimpin kelompok (guru BK) mulai membicarakan kesan dan pesan dalam kegiatan konseling kelompok kemudian ,emgakhiri dengan membuat jadwal kegiatan lanjutan apabila belum terselesaikan dalam satu kali sesi konseling (Priyatno, 1995). 
Hasil penelitian menyatakan bahwa ada beberapa faktor yang biasanya mendorong terjadinya konflik antar suku pada peserta didik. Seperti yang diungkapkan oleh guru BK dalam wawancara sebagai berikut:

“..sebenarnya pemicu masalah ini faktornya sangat banyak seperti kurangnya pemahaman antar suku, rendahnya toleransi, kurang harmonis dengan suku lain, sulit beradaptasi dengan suku lain, masih ada penanaman nilai negatif didalam keluarga bahwa suku yang paling ungggu hanya suku mereka sendiri sedangkan suku lain dianggap rendah.."

Karena konflik yang muncul tersebut maka guru Bimbingan dan Konseling menindak lanjuti dengan melakukukan konseling kelompok. Setelah dilaksanakan kegiatan konseling kelompok, peserta didik dapat mengungkapkan pendapatnya terkait cara membangun toleransi terhadap perbedaan suku, adapun ungkapan peserta didik sebagai berikut: “..bisa dengan cara membangun silahturahmi, bersikap ramah tanpa membedabedakan suku, yang pasti menghargai adat antar sesama, serta saling menghormati dan bersikap baik kepada semua orang tanpa melihat perbedaan."

Dengan demikian, peserta didik diminta untuk mengungkapkan tanggapan dan perasaan jika suku mereka mendapat anggapan negatif, ungkapan dapat dilihat di antaranya sebagai berikut:

“..kalau itu kembali kepada individu masing-masing. Tapi sebagai manusa kita tetap harus berbuat baik kepada orang lain walaupun mereka tidak suka dengan kita. Karena pada dasarnya kita tidak bisa menyamakan semua hal, yang memandang jika satu orang buruk, artinya butuk semua tanpa terkecuali.."

Adapun yang mengungkapkan kekesalannya, namun setelah sesi konseling peserta didik mengerti bahwa manusia diciptakan dengan berbagai perbedaan, keunikan serta kelebihan dan kekurangan, adapun ungkapan peserta didik sebagai berikut :

“..saya pasti sedih dan kesal dan tidak terima jika ada anggapan negatif mengenai suku saya. Tapi ya balik lagi setelah sesi konseling ini saya mengerti dan memahami bahwa semua orang itu unik, berbeda tentunya dan memiliki kekurangan dan kelebihan masing-masing.."

Ada juga peserta didik yang kemudian tidak memperdulikan hal tersebut:

“..biarkan saja, itu anggapan mereka terhadap suku saya dan tugas saya tetap berbuat baik dan bagaimana caranya anggapan itu dapat berubah. Sehingga kita tepat bisa berteman baik dengan semua orang tanpa memandang perbedaan yang 
ada dan jangan sampai perbedaan yang ada kita jadikan alasan untuk saling membeda-bedakan."

Dari hasil tanggapan peserta didik menunjukkan bahwa setelah dilakukan kegiatan konseling kelompok, peserta didik lebih bisa melakukan penerimaan dan menjadi lebih baik lagi sehingga perlahan dapat membangun keharmonisan antar suku di lingkungan sekolah

\section{KESIMPULAN}

Uraian di atas menyiratkan urgensi konseling religius yang berlandaskan pada filosofis, regulatif, empiris, psikologis, budaya dan pengalaman beragama. Landasan filosofis sebagai pusat penerapan konseling religius dengan menempatkan manusia sebagai ciptaan Tuhan, keyakinan pada Tuhan dan ketundukan aturan yang ditetapkan Tuhan. Urgensi bimbingan dan konseling religius juga ditopang dengan kebijakan yang telah ditetapkan oleh pemerintah, baik melalui Undang-Undang maupun peraturan pemerintah lainya. Agar implementasi konseling religius dapat terwujud, maka dalam tataran teknis penambahan kompetensi religius pada konselor perlu dimasukkan dalam kurikulum pendidikan calon konselor atau guru pembimbing.

\section{DAFTAR RUJUKAN}

Creswell, J.W. (2017). Research Design Pendekatan Metode Kualitatif, Kuantitatif, dan Campuran Edisi Keempat. Pustaka Pelajar: Yogyakarta.

Herawati. (2018). Memahami Proses Belajar Anak. Dayah: Journal of Islamic Education, $4(1), 27-48$

Hidayat, R., Azwar, B., Harmi, H., Sumarto, Wanto, D., Daheri, M. (2019) Sindang Jati Multikultural Dalam Bingkai Moderasi. Bengkulu: Penerbit Buku Rasiologi.

Megantari, N.P., Antari, N.N.M., Dantes, N. (2014). Penerapan Konseling Behavioral Dengan Self Management Untuk Meningkatakan Disiplin Belajar Siswa Kelas X Mia-4 Sma Negeri 3 Singaraja. E-Journal Undiksa Jurusan Bimbingan Konselng, 2(1), 1-10.

Miyanti, C.Y., Rini, H.S., Luthfi, A. (2017). Konflik Dalam Relasi Sosial Masyarakat Jawa Dan Lampung Di Wilayah Transmigrasi (Studi Kasus di Desa Bandar Agung Kecamatan Bandar Sribhawono Kabupaten Lampung Timur). Solidarity, 6(2), 189201.

Muzaki, I, A. \& Tafsir, A. (2018) Pendidikan Multikultural Dalam Perspektif Islamic Worldview. Jurnal Penelitian Pendidikan Islam, 6(1), 57-76.

Priytano, (1995). Buku Seri Bimbingan dan Konseling di Sekolah, Layanan Bimbingan dan Konseling Kelompok (Dasar dan Profil). Jakarta: Ghalia Indonesia.

Sari, N.K.K.U., Gading, I.K., Dharsana, I.K. (2020). Development of Group Counseling: A Guidebook in Lesson Study to Increase Creativity. Bisma: The Journal of Counseling, 4(2), 108-115

Winkel S.J. \& Sri Hatuti. (2004). Bimbingan dan Konseling di Industri Pendidikan. Yogyakarta: Media Abadi. 